Article

\title{
Antiviral Potential of Sea Urchin Aminated Spinochromes against Herpes Simplex Virus Type 1
}

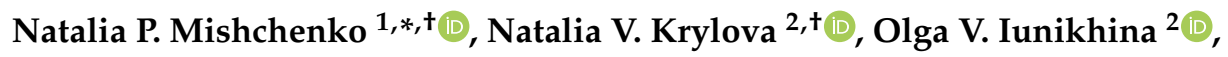

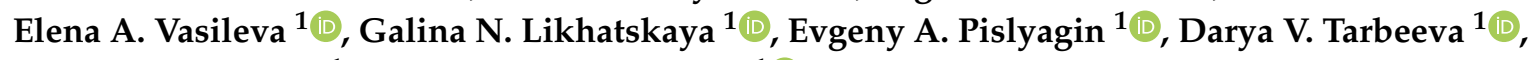 \\ Pavel S. Dmitrenok ${ }^{1}$ and Sergey A. Fedoreyev ${ }^{1}$ D \\ 1 G.B. Elyakov Pacific Institute of Bioorganic Chemistry, Far-Eastern Branch of the Russian Academy \\ of Sciences, 690022 Vladivostok, Russia; vasilieva_el_an@mail.ru (E.A.V.); galinlik@piboc.dvo.ru (G.N.L.); \\ pislyagin@hotmail.com (E.A.P.); tarbeeva1988@mail.ru (D.V.T.); paveldmitrenok@mail.ru (P.S.D.); \\ fedoreev-s@mail.ru (S.A.F.) \\ 2 G.P. Somov Institute of Epidemiology and Microbiology, Far-Eastern Branch of the Russian Academy \\ of Sciences, 690087 Vladivostok, Russia; krylovanatalya@gmail.com (N.V.K.); olga_iun@inbox.ru (O.V.I.) \\ * Correspondence: mischenkonp@mail.ru; Tel.: +79-084542965 \\ $+\quad$ N.P.M. and N.V.K. contributed equally to this manuscript.
}

Received: 14 October 2020; Accepted: 2 November 2020; Published: 5 November 2020

\begin{abstract}
Herpes simplex virus type 1 (HSV-1) is one of the most prevalent pathogens worldwide requiring the search for new candidates for the creation of antiherpetic drugs. The ability of sea urchin spinochromes-echinochrome A (EchA) and its aminated analogues, echinamines A (EamA) and B (EamB) - to inhibit different stages of HSV-1 infection in Vero cells and to reduce the virus-induced production of reactive oxygen species (ROS) was studied. We found that spinochromes exhibited maximum antiviral activity when HSV-1 was pretreated with these compounds, which indicated the direct effect of spinochromes on HSV-1 particles. EamB and EamA both showed the highest virucidal activity by inhibiting the HSV-1 plaque formation, with a selectivity index (SI) of 80.6 and 50.3, respectively, and a reduction in HSV-1 attachment to cells (SI of 8.5 and 5.8, respectively). EamA and EamB considerably suppressed the early induction of ROS due to the virus infection. The ability of the tested compounds to directly bind to the surface glycoprotein, gD, of HSV-1 was established in silico. The dock score of EchA, EamA, and EamB was $-4.75,-5.09$, and $-5.19 \mathrm{kcal} / \mathrm{mol}$, respectively, which correlated with the SI of the virucidal action of these compounds and explained their ability to suppress the attachment and penetration of the virus into the cells.
\end{abstract}

Keywords: echinochrome A; echinamine A; echinamine B; herpes simplex virus type 1; Vero cells; glycoprotein $\mathrm{gD}$; molecular docking

\section{Introduction}

According to the World Health Organization, herpes simplex virus (HSV) infections are the second most common viral disease in humans after influenza [1]. HSV type 1 (HSV-1) is a neurotropic virus that can persist in human sensory neurons for life, replicate in epithelial cells during primary infection and reactivation, and cause diseases with a variety of clinical manifestations, from labial herpes to meningitis and encephalitis [2]. Recently, the number of reports on the resistance of HSV-1 against many drugs based on nucleoside analogues, which are acyclovir and its derivatives, has increased [3-5]. Therefore, the search for new antiviral drugs, specifically anti-HSV drugs, remains an important problem.

Many of the cytopathic effects observed during HSV-1 infection are not only due to viral replication but also to oxidative stress caused by the virus, leading to cell damage [6-8]. Therefore, using exogenous 
antioxidants capable of counteracting the destructive effect of virus-induced oxidative stress on cells is considered a promising strategy [9]. Currently, many laboratories around the world are actively studying antioxidants with different chemical structures as potential therapeutic agents for herpes infection treatment. The largest number of studies on the antiherpetic activity of natural antioxidants is associated with the study of polyphenolic compounds from terrestrial and marine plants $[10,11]$. In this regard, a class of marine natural polyphenolic compounds found in representatives of Echinodermata, such as sea urchins, sea stars, and ophiurs, is promising [12]. This class is called spinochromes and has been known for over 100 years; nevertheless, extensive investigations of the biological activities of these compounds began only in the last decade $[13,14]$.

Recently, our group discovered the antiviral properties of the most abundant and well-known spinochrome, echinochrome A (EchA), as well as an antioxidant composition consisting of EchA in combination with ascorbic acid and $\alpha$-tocopherol. It was found that EchA and the composition effectively inhibit the cytopathogenic effect of HSV-1 and tick-borne encephalitis virus [15]. EchA and the antioxidant composition have shown a considerable protective effect on the mouse model of genital HSV type 2 (HSV-2) infection. Both intraperitoneal and oral administration of EchA and the composition significantly improved the survival rate and reduced the vaginal virus load of HSV-2-infected mice [16]. The potential affinity of sea urchin pigments to bind the main protease (Mpro) and the spike protein (S) of SARS-CoV-2 was evaluated in silico [17,18]. EchA showed high affinity to both targets, which indicated its potential as an antiviral drug against SARS-CoV-2 and encouraged further in vitro and in vivo analysis to expand its therapeutic uses.

The first spinochromes containing a primary amino group, echinamines A (EamA) and B (EamB), which are aminated derivatives of EchA, were isolated in 2005 from the flat sea urchin Scaphechinus mirabilis [19]. Nowadays, amino derivative of spinochrome E-spinamine E [20] has also been isolated from various species of sea urchins, and the new aminated quinonoid pigment acetylaminotrihydroxynaphthoquinone [21] was detected in the sea urchin Strongylocentrotus nudus using UPLC-DAD-MS (ultra performance liquid chromatography-diode array detector-mass spectrometry). The natural origin of these spinochromes is beyond doubt; they were found in both the regular sea urchins Strongylocentrotus nudus, S. pallidus, and S. polyacanthus and the irregular sea urchins Echinarachnius parma and Scaphechinus mirabilis, which inhabit the southern and northern seas at different depths up to 200 $\mathrm{m}$ [20-23]. The simultaneous presence of three aminated spinochromes-EamA, EamB, and spinamine E-was found in the commercial sea urchin Evechinus chloroticus from New Zealand, also known as kina [23].

A number of investigations have reported that spinochromes are strong antioxidants that can block a number of free radical reactions, inhibit lipid peroxidation, and reduce and chelate metal ions [21,24-27]. Recently, using 2,2-diphenyl-1-picrylhydrazyl radical (DPPH) and lipid autooxidation assays, it has been shown that aminated spinochromes EamA and EamB and spinamine E are more potent antioxidants than their hydroxylated analogues [20].

Thus, the aim of this study was to evaluate the anti-HSV-1 activity of EamA and EamB in vitro and in silico as well as their effect on the HSV-1-induced production of reactive oxygen species (ROS) in Vero cells, in comparison with EchA.

\section{Results and Discussion}

\subsection{Physico-Chemical Properties of Aminated Spinochromes}

Spinochromes of the sea urchin Echinarachnius parma were isolated using a previously described standard procedure [20]: shells were treated with ethanol containing $10 \%$ sulfuric acid, and the sum of the pigments was extracted with chloroform and ethyl acetate and then fractionated using repeated column chromatography on Toyopearl HW-40 gel (TOYO SODA, Tokyo, Japan). As a result, EchA, EamA, and EamB were isolated (Figure 1A). According to HPLC-MS (high performance liquid 
chromatography mass spectrometry) data, E. parma extracts also contained spinochromes D and E and three binaphthoquinones [22], which were not used in this study.
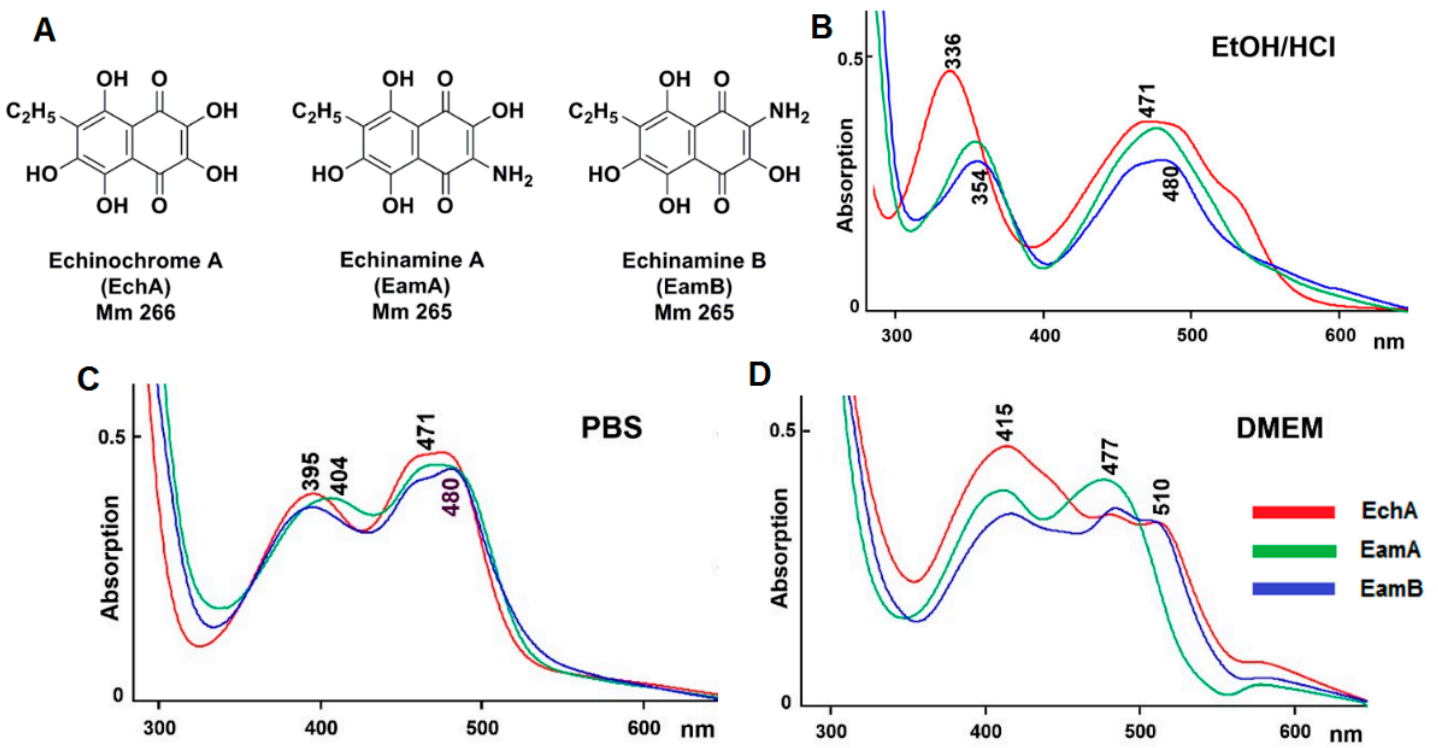

Figure 1. (A) Structural formulae of the studied spinochromes. Absorption spectra of the studied spinochromes $(0.02 \mathrm{mg} / \mathrm{mL})$ in (B) acidified ethanol ( $\mathrm{pH} 1.0),(\mathbf{C})$ phosphate buffered saline (PBS); 0.01 M, pH 7.2, and (D) Dulbecco's Modified Eagle's Medium (DMEM) (pH 7.2). Compound spectra were recorded in comparison to the corresponding solvent.

The content of aminated spinochromes in E. parma was not higher than $3 \%$ of the total amount of quinonoid pigments, which was not enough for biological activity investigations. Recently, several simple and effective synthesis schemes of EamA and EamB have been described [28-32]. However, the most promising method developed by us for obtaining EamA and EamB is the amination of EchA with aqueous ammonia [29]. This reaction led to the formation of a mixture of EamA and EamB in nearly quantitative overall yield, which was successfully separated by column chromatography on a Sephadex LH-20. The HPLC-MS and NMR characteristics of the obtained EamA and EamB coincided with the data of natural echinamines (Supplementary Materials, page 3, Figure S1).

Earlier, we described two specific differences of the aminated spinochromes from their hydroxylated analogues. They have one unit less molecular weight compared to the corresponding hydroxylated spinochrome, and the quinoid electron transfer band in the absorption spectrum of the aminated spinochromes is usually 10-15 $\mathrm{nm}$ bathochromically shifted compared with that of their hydroxylated analogues [20]. As seen from in Figure 1B, this is true for both EamA and EamB.

It is known that small-molecule drug substances are ionisable under physiological conditions, forming a number of protomers [33]. Under physiological conditions, for example, in phosphate buffer PBS pH 7.2, all studied spinochromes become ionisable, reflecting a shift in the quinoid absorption band to about $400 \mathrm{~nm}$ (Figure 1C). The possible protomeric structures of each spinochrome in the aqueous phase with physiological pH were calculated using MOE 2019.01 software (Figure S2). Under these conditions, echinochrome A forms the largest number of protomers, in which the quinoid fragment of the molecule is presented in the form of triketone, and the negative charge is delocalised in the benzene fragment. The smallest number of protomers was obtained for EamB, one of which takes $77 \%$ of the possible structures. Knowledge of the structures of protomers is important for predicting their properties since they determine the binding with biological molecules [34,35]. The absorption spectra of spinochromes in Dulbecco's Modified Eagle's Medium (DMEM) containing glucose, vitamins, salts, L-glutamine, and other amino acids, differed significantly (Figure 1D), possibly due to the presence of different protomeric forms of these compounds in solution, which define the binding with the components of the DMEM. 


\subsection{Cytotoxicity and Anti-HSV-1 Activity of the Tested Compounds}

The cytotoxicity of the spinochromes and acyclovir (ACV) as a positive control against Vero cells was evaluated before testing their antiviral activity. Cells were treated with concentrations of spinochromes from 1 to $200 \mu \mathrm{g} / \mathrm{mL}$ and of ACV from 1 to $1000 \mu \mathrm{g} / \mathrm{mL}$ for $72 \mathrm{~h}$, and cell viability was assessed using the MTT (methylthiazolyltetrazolium bromide) assay. There was no significant difference $(p>0.05)$ between the $50 \%$ cytotoxic concentrations $\left(C_{50}\right)$ of the studied spinochromes; their mean $\mathrm{CC}_{50}$ values were $\sim 140 \mu \mathrm{g} / \mathrm{mL}$, while the $\mathrm{CC}_{50}$ of ACV was above $1000 \mu \mathrm{g} / \mathrm{mL}$ (Table 1 ). Therefore, the antiviral activity of the tested compounds against HSV-1 was determined at concentrations below $100 \mu \mathrm{g} / \mathrm{mL}$.

Table 1. Effects of the tested compounds at different stages of herpes simplex virus type 1 (HSV-1) infection.

\begin{tabular}{|c|c|c|c|c|c|c|c|}
\hline Compounds & $\mathrm{CC}_{50}$ & \multicolumn{6}{|c|}{$\mathrm{IC}_{50}(\mathrm{SI})$} \\
\hline EamA & $146 \pm 7$ & $2.9 \pm 0.4(50.3) *$ & $96 \pm 16(1.5)$ & $25 \pm 4(5.8)$ & $56 \pm 8(2.6)$ & $34 \pm 6(4.3)$ & $113 \pm 23(1.3)$ \\
\hline EamB & $137 \pm 6$ & $1.7 \pm 0.2(80.6)$ * & $92 \pm 14(1.5)$ & $16 \pm 3(8.5) *$ & $54 \pm 7(2.5)$ & $30 \pm 5(4.6)$ & $80 \pm 14(1.7)$ \\
\hline $\mathrm{ACV}$ & $>1000$ & NA & NA & NA & NA & $2.1 \pm 0.4(476)$ & $\begin{array}{c}0.1 \pm 0.02 \\
(10,000)\end{array}$ \\
\hline
\end{tabular}

Values are presented as the means \pm standard deviations. $\mathrm{CC}_{50}(\mu \mathrm{g} / \mathrm{mL}), 50 \%$ cytotoxic concentration; $\mathrm{IC}_{50}(\mu \mathrm{g} / \mathrm{mL})$, concentration that inhibited $50 \%$ of HSV-1 plaque formation; SI, selectivity index $\left(\mathrm{CC}_{50} / \mathrm{IC}_{50}\right)$; NA, no activity. * Statistically significant differences between values of EchA and the echinamines $(p \leq 0.05)$.

The inhibitory effect of the tested compounds on different stages of HSV-1 infection was studied by a plaque reduction assay. We used the following treatment schemes [36]: pretreatment of the virus (compounds were added directly to the virus suspension); pretreatment of the cells (cells were treated with compounds for $1 \mathrm{~h}$ before infection); attachment (cells were co-treated with the virus and compounds at $4{ }^{\circ} \mathrm{C}$ ); penetration (cells were infected with the virus at $4{ }^{\circ} \mathrm{C}$ and then treated with the compounds at $37^{\circ} \mathrm{C}$ ); and simultaneous and post-infection treatment (cells were treated with the compounds at the same time as infection or $1 \mathrm{~h}$ after infection). The antiviral effect of the tested compounds was compared to that of the untreated virus after $72 \mathrm{~h}$ of incubation, and the obtained results were used for calculations of the concentration yielding a $50 \%$ reduction in plaque formation $\left(\mathrm{IC}_{50}\right)$ and the selectivity index (SI) as the ratio of $\mathrm{CC}_{50}$ to $\mathrm{IC}_{50}$ for each of the compounds.

The pretreatment of HSV-1 (100 plaque-forming units (PFU)/mL) with different concentrations ( 0.2 to $25 \mu \mathrm{g} / \mathrm{mL}$ ) of the tested spinochromes and ACV showed that the spinochromes significantly inhibited HSV-1-induced plaque formation, with $\mathrm{IC}_{50}$ values of less than $5 \mu \mathrm{g} / \mathrm{mL}$ (Table 1, Figure S3). Among the three tested compounds, EamB was found to have the highest SI value (80.6) against HSV-1. In comparison, ACV did not show antiviral activity, even when tested up to a concentration of $100 \mu \mathrm{g} / \mathrm{mL}$. These results indicate the direct effect of spinochromes on HSV-1 particles, with the virucidal activity of EamA and EamB being significantly higher $(p \leq 0.05)$ than that of EchA.

The treatment of Vero cells with the tested compounds before infection (pretreatment of cells) had no effect on HSV-1 plaque formation. Post-infection treatment of cells with spinochromes was also ineffective in contrast to ACV (SI of $~ 1.5$ vs. 10,000), which is known to block viral replication [37]. Next, the tested compounds and HSV-1 were added to Vero cells simultaneously to investigate their influence on the early stages of viral infection. In this assay, spinochromes displayed moderate inhibitory activity against HSV-1 ( $\mathrm{IC}_{50}>30 \mu \mathrm{g} / \mathrm{mL}$; SI of $\sim 4.3$ ) (Table 1).

Thus, the results of HSV-1 pretreatment with spinochromes and the results of simultaneous treatment of cells with HSV-1 and spinochromes revealed that these compounds affect the very early stages of the HSV-1 life cycle, which are the attachment and penetration stages.

The attachment and penetration stages were analysed by shifting the temperature during the infection. It is known that for many enveloped viruses, including HSV-1, a temperature of $4{ }^{\circ} \mathrm{C}$ 
allows for virus attachment to host cells, but not cell penetration, whereas a temperature of $37^{\circ} \mathrm{C}$ facilitates virus penetration into the cells [38-40]. In the attachment assay, during which Vero cells were co-treated with HSV- 1 and tested compounds at $4{ }^{\circ} \mathrm{C}$, EamA and EchA displayed a moderate inhibitory effect on the binding of the virus to cells (Table 1). At the same time, EamB significantly reduced $(p \leq 0.05)$ the HSV-1 attachment to cells $(\mathrm{SI}=8.5)$ compared to EchA $(\mathrm{SI}=4.3)$. For the penetration assay, cells were infected with HSV- 1 at $4{ }^{\circ} \mathrm{C}$ and then treated with test compounds at $37^{\circ} \mathrm{C}$ to facilitate virus entry into the cells. The results showed that the effect of spinochromes on viral entry was not significant (SI of $~ 2.5$ ). ACV did not affect the attachment and penetration stages of HSV-1 infection when tested up to a concentration of $100 \mu \mathrm{g} / \mathrm{mL}$.

Thus, it was shown that the tested spinochromes (EamA, EamB, and EchA) exert significant anti-HSV-1 activity, mainly due to their direct virucidal properties, but they also inhibit the attachment of the virus to cells and, to a lesser extent, virus penetration into cells.

\subsection{Effect of Spinochromes on HSV-1-Induced Intracellular ROS Production}

To determine whether HSV-1 infection induced ROS production, Vero cells were infected with HSV-1 at $100 \mathrm{PFU} / \mathrm{mL}$. At different time points after infection (1, 2, 3, and $4 \mathrm{~h})$, the cells were loaded with the fluorogenic marker (DCF-DA $\left(2^{\prime}, 7^{\prime}\right.$-dichlorofluorescein diacetate)), and ROS production was assessed by changes in the mean fluorescence intensity in the control (uninfected cells) versus the infected cells. The results reported in Figure 2A show that HSV-1 infection of Vero cells induced a significant increase in ROS production at 1 and $2 \mathrm{~h}$ post-infection $(p \leq 0.05)$, but at 3 and $4 \mathrm{~h}$ post-infection the levels of ROS production in the infected cells did not differ from those in the control. These results indicated that HSV-1 was able to induce a high level of ROS at a very early stage of infection, which has also been confirmed by other authors [8,41].

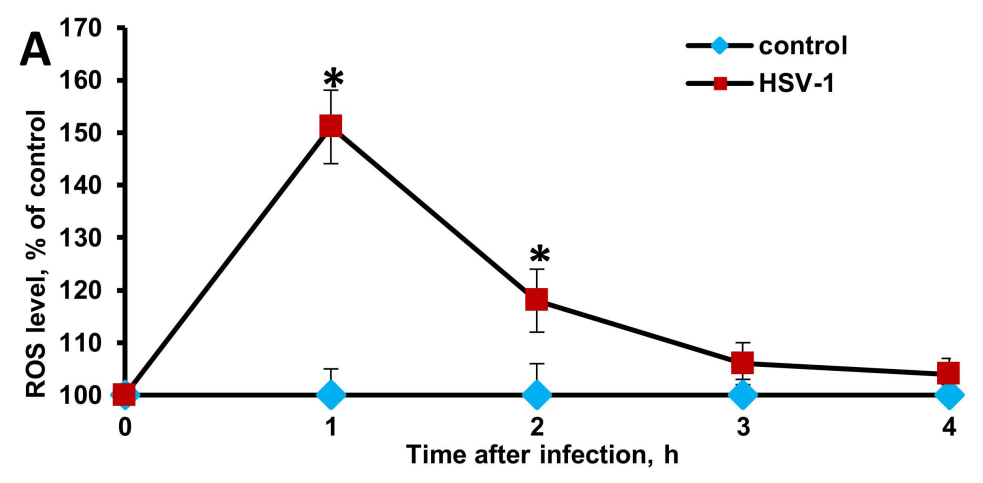

B

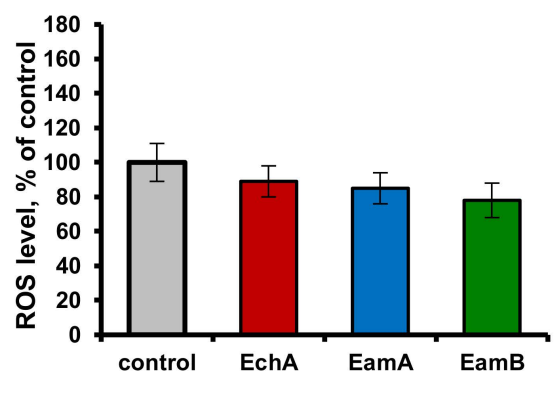

C

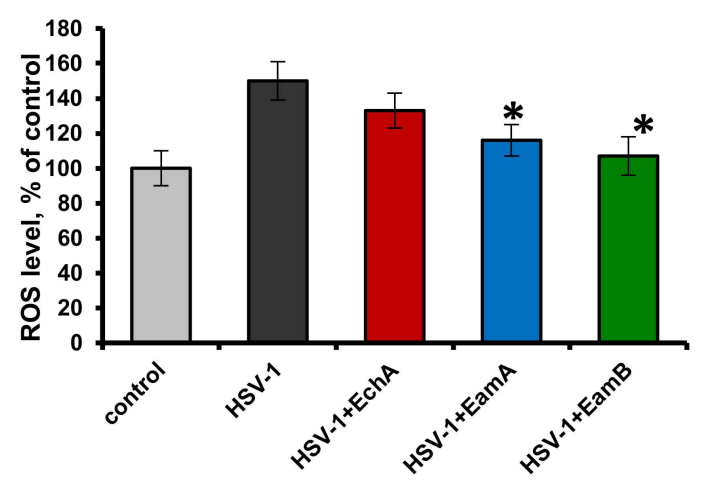

Figure 2. Effects of HSV-1 and spinochromes on reactive oxygen species (ROS) levels in Vero cells. The DCF-DA (2', $7^{\prime}$-dichlorofluorescein diacetate) assay was used to measure the cellular ROS. (A) Dynamics 
of HSV-1-induced intracellular ROS levels compared to uninfected cells (control). Data are presented as the mean \pm SD of three independent experiments. ${ }^{*} p \leq 0.05$ compared with the control. (B) Effects of the studied spinochromes $(5 \mu \mathrm{g} / \mathrm{mL})$ on the ROS levels in uninfected cells. (C) Effects of HSV-1 $(100 \mathrm{PFU} / \mathrm{mL})$ on ROS levels after incubation for $1 \mathrm{~h}$ with spinochromes $(5 \mu \mathrm{g} / \mathrm{mL})$. The results include data from three experiments (mean $\pm \mathrm{SD}$ ). ${ }^{*} p \leq 0.05$ compared with HSV-1-infected cells.

The next task was to find out whether the spinochromes could affect the HSV-1-induced ROS production in Vero cells. Since the tested compounds exhibited significant anti-HSV-1 activity, mainly due to direct inactivation of viral particles, as noted above, to study their effect on virus-induced ROS production, HSV-1 was pre-incubated with these compounds. In these experiments, spinochromes were used at a concentration of $5 \mu \mathrm{g} / \mathrm{mL}$, which is approximately equal to the $\mathrm{IC}_{50}$ concentration calculated for them in the virucidal assay. At first, it was found that the tested compounds themselves, when added to Vero cells for $2 \mathrm{~h}$, did not cause a significant decrease in ROS production compared to the cell control $(p>0.05)$ (Figure 2B). At the same time, pretreatment of HSV-1 (100 PFU/mL) with EamA and EamB followed by the $1 \mathrm{~h}$ exposure of these mixtures on Vero cells significantly inhibited the early induction of ROS formation by the virus compared with untreated HSV-1-infected cells $(p \leq 0.05)$ (Figure 2C).

\subsection{Molecular Docking}

HSV-1 surface glycoproteins are involved in the processes of adhesion and fusion of the virus with the cell membrane. The HSV-1 glycoprotein $\mathrm{gD}$ is involved in the interaction of the virus with the cellular receptors nectin-1, HSEA/M, and 3-O-sulphated heparan sulphate (3-OS HS) [42,43]. The interaction of the $\mathrm{gD}$ protein with the receptors triggers the adhesion of the virus to the cell and fusion with the cell membrane. This protein can be used as a target protein to search for compounds that inhibit the initial stages of HSV-1 infection. It was shown with molecular docking that flavonoid myricetin can block HSV infection by directly interacting with the viral gD protein and interfering with virus adsorption [44].

In this work, the interaction of spinochromes with the HSV-1 surface glycoprotein, gD, was studied using molecular docking methods, and it was shown that the studied compounds can directly bind to $\mathrm{gD}$, competing for binding sites of this protein with cellular receptors (nectin-1 and 3-OS HS), thereby preventing the adsorption of the virus to cells.

The search for binding sites for the gD glycoprotein showed that one of the sites overlaps with the site for $\mathrm{gD}$ binding to the nectin-1 cellular receptor (Figure S4). Molecular docking of spinochromes into this site showed that spinochromes have two subsites on $\mathrm{gD}$ (Figure 3). Analysis of the contacts of the spinochromes with $\mathrm{gD}$ showed that the compounds under study form hydrogen bonds with amino acid residues of $\mathrm{gD}$, including the arginine (Arg) 222 residue, which is important for binding to the nectin-1 receptor (Figure 4).

Apparently, the interaction of spinochromes with Arg 222 inhibits the binding of gD to the cellular receptor, nectin-1. The dock score of EchA, EamA, and EamB in Subsite 1 with gD was -4.75 , -5.09 , and $-5.19 \mathrm{kcal} / \mathrm{mol}$, respectively, and correlated with the SI values obtained in the virucidal and attachment analysis (Table 1).

The interaction of $\mathrm{gD}$ and 3-OS HS is a key step for triggering the fusion of the virus and cells [43]. Calculation of the electrostatic potential of the molecular surface of the $\mathrm{gD}$ protein showed that there are positively charged sites on the surface of the viral protein that can potentially interact with 3-OS HS. The interactions of the 3-OS HS tetrasaccharide and the spinochromes with the glycoprotein, $\mathrm{gD}$, at a positively charged site were tested. It was shown by molecular docking that the 3-OS HS tetrasaccharide and the spinochromes compete for interaction with Arg 67 and Arg 64 residues of the gD protein (Figures 5 and 6 ). The in silico results allowed for a better understanding and clarification of the mechanism underlying the in vitro anti-HSV-1 action of the spinochromes. The ability of the tested compounds to directly bind to the gD surface of the HSV-1 virus, to compete with the cellular receptors 
for binding sites on this glycoprotein, and to suppress the attachment and penetration of the virus into the cells was established. Blocking the early stages of HSV-1 infection may be an attractive therapeutic strategy, the advantage of which is that it can prevent the spread of the virus without killing virus-infected cells, as occurs with acyclovir.

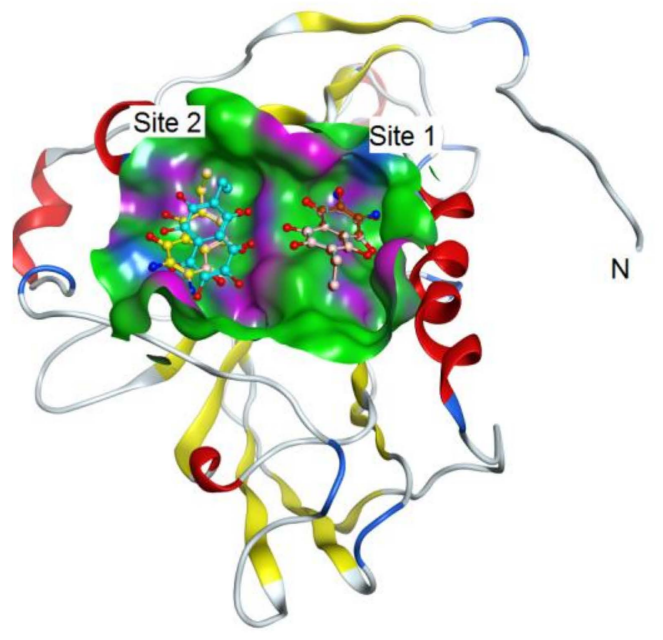

(A)

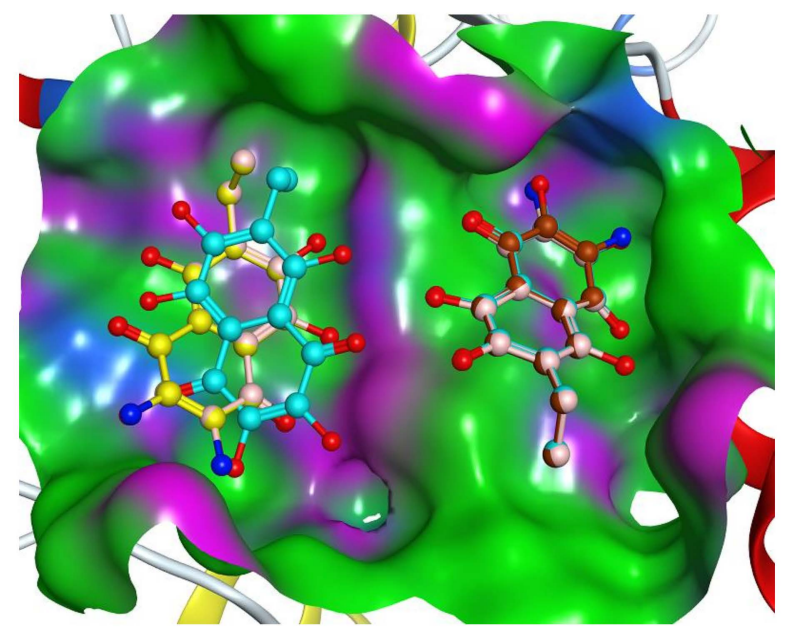

(B)

Figure 3. Molecular docking of spinochromes with gD. (A) Subsites 1 and 2 of binding of spinochromes to $\mathrm{gD}$. Spinochrome structures are shown in colour as balls and sticks. The gD molecule is shown as a ribbon. (B) Molecular surface of $\mathrm{gD}$ in the binding sites of the spinochromes. Site 1: EchA (turquoise), EamA (beige), EamB (brown); Site 2: EchA (turquoise), EamA (beige), EamB (yellow). The colour shows the molecular surface of gD: H-bonding (pink), hydrophobic (green), and mild polar (blue).

EchA

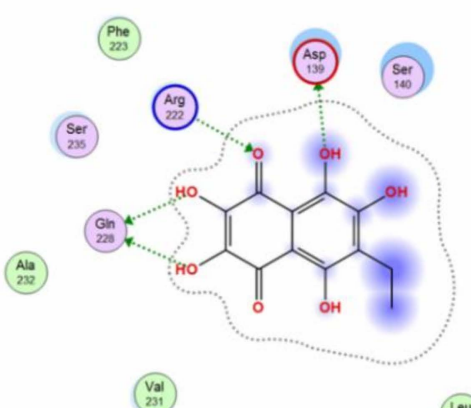

(val

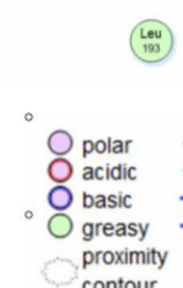

EamA

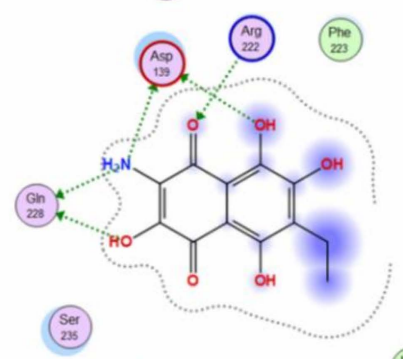

(2)

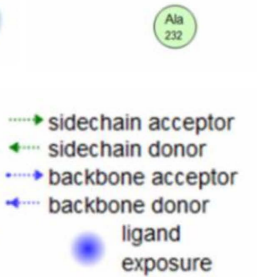

(ivg)

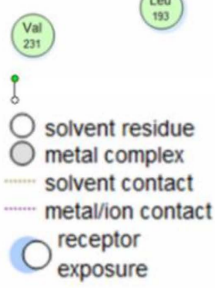

EamB

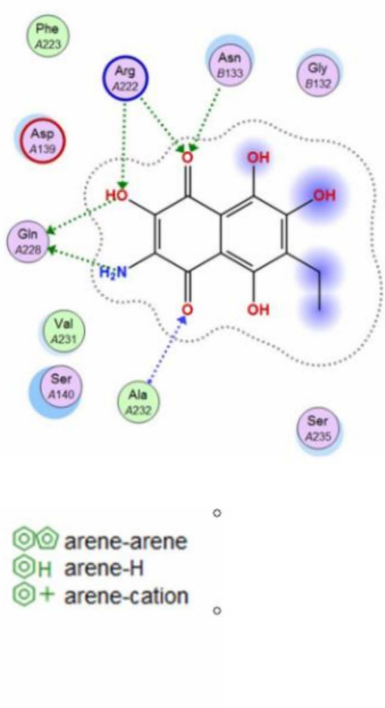

Figure 4. 2D diagrams of EchA, EamA, and EamB contacts with the HSV-1 glycoprotein gD. Abbreviations of aminoacids: alanine (Ala); arginine (Arg); aspartic acid (Asp); asparagine (Asn); glutamine (Gln); glycine (Gly); leucine (Leu); phenylalanine (Phe); serine (Ser); valine (Val). 


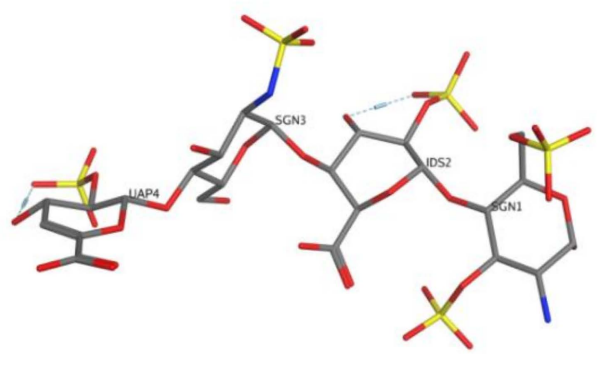

(A)

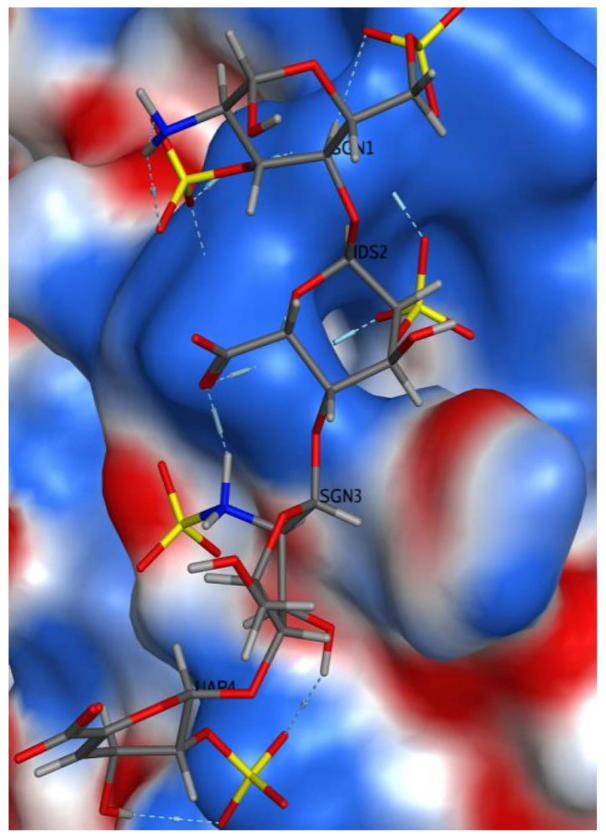

(C)

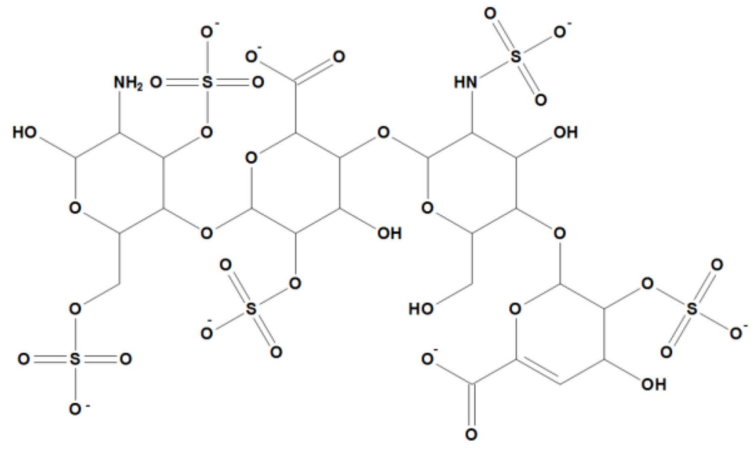

(B)

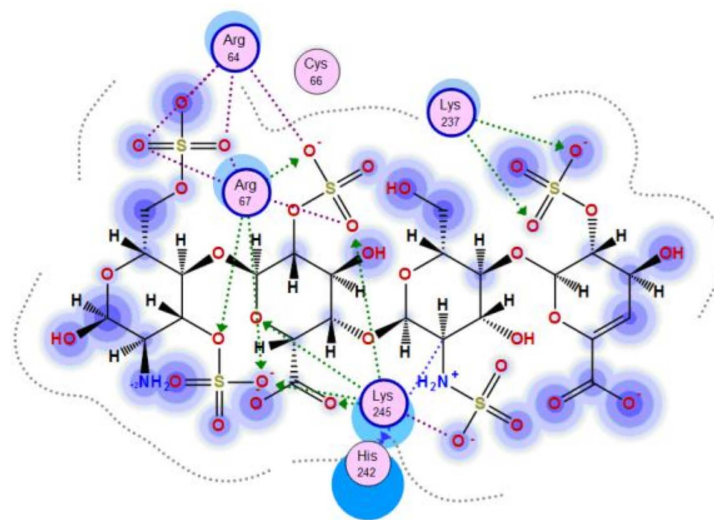

$\left(\begin{array}{ll}619 \\ 243\end{array}\right.$

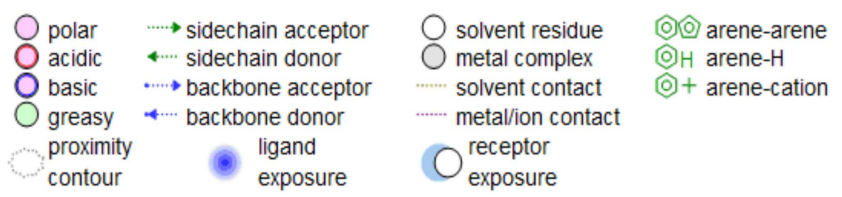

(D)

Figure 5. Molecular docking of the 3-O-sulphated heparan sulphate (3-OS HS) tetrasaccharide and the herpes simplex virus type 1 (HSV-1) gD membrane glycoprotein. (A) 3D structure and (B) 2D structure of 3-OS HS obtained using the MOE program. (C) The putative binding site of 3-OS HS and gD HSV-1. (D) 2D diagram of the contacts of 3-OS HS with gD.

A

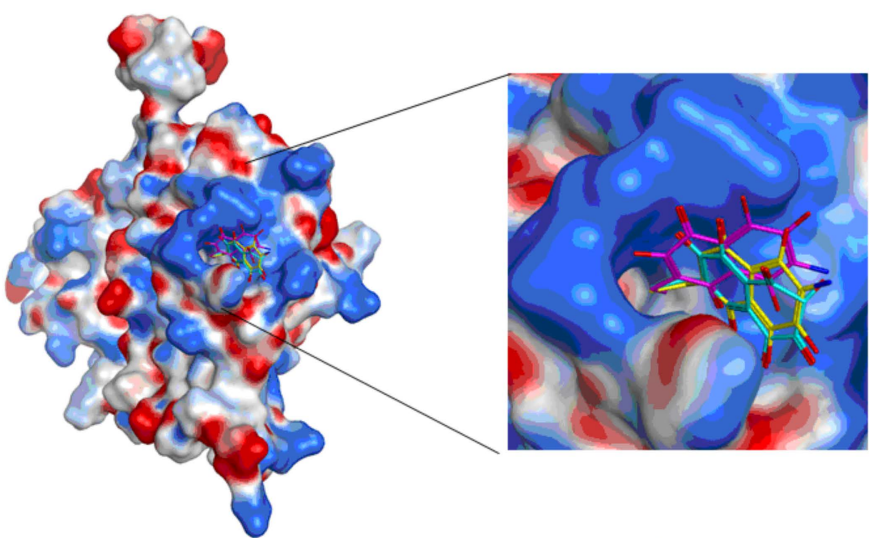

Figure 6. Cont. 
B

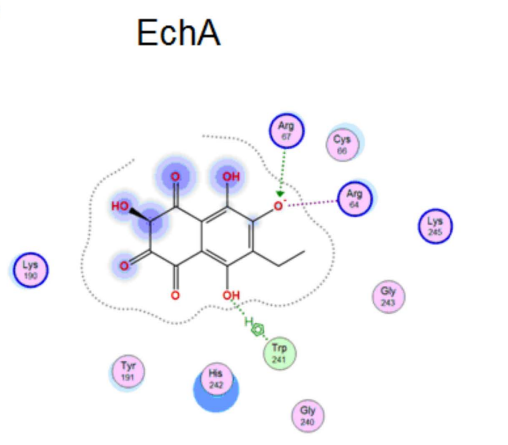

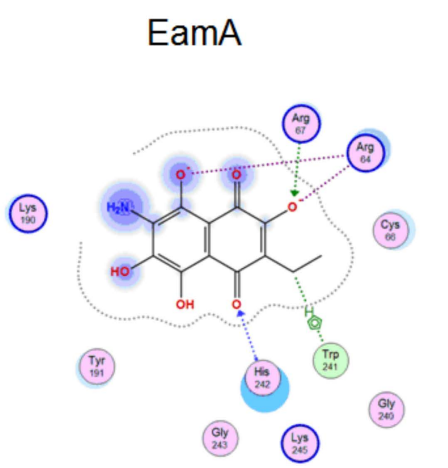

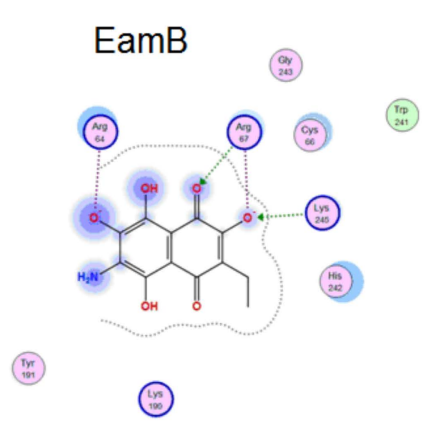

Figure 6. (A) Molecular docking of spinochromes into a potential binding site of the 3-OS HS tetrasaccharide and the HSV-1 gD membrane glycoprotein. The electrostatic potential of the gD molecular surface was calculated using the MOE 2019.01 program. The spinochrome structures are shown as sticks. (B) 2D diagram of contacts of EchA, EamA, and EamB protomers with gD.

\section{Materials and Methods}

\subsection{Reagents}

DMEM (Biolot, St. Petersburg, Russia), fetal bovine serum (FBS, Biolot, Saint Petersburg, Russia), gentamycin (Dalkhimprom, Khabarovsk, Russia), Acyclovir ${ }^{\circledR}$ (ACV; freeze-dried powder for injections; GlaxoSmithKline Pharmaceuticals S.A., Poznan, Poland), dimethylsulfoxide (DMSO; Sigma, Saint-Louis, MO, USA), methylthiazolyltetrazolium bromide (MTT; Sigma, Saint-Louis, MO, USA), 2' , 7'-dichlorofluorescein diacetate (DCF-DA; Sigma, Saint-Louis, MO, USA), carboxymethyl cellulose (CMC; MP Biomedicals, Inc., Aurora, OH, USA), crystal violet (Sigma, Saint Louis, MO, USA), and phosphate buffered saline (PBS, Sigma, Saint-Louis, MO, USA) were used.

\subsection{Viruses and Cell Cultures}

HSV-1 strain L2 was obtained from N.F. Gamaleya Federal Research Centre for Epidemiology and Microbiology, Moscow, Russia. HSV-1 was grown in African green monkey kidney (Vero) cells using DMEM supplemented with $10 \% \mathrm{FBS}$ and $100 \mathrm{U} / \mathrm{mL}$ of gentamycin at $37^{\circ} \mathrm{C}$ in a $\mathrm{CO}_{2}$ incubator. In the maintenance medium, the FBS concentration was decreased to $1 \%$.

\subsection{Spinochromes Isolation}

The sea urchin Echinarachnius parma (Lamarck, 1816) was collected by dredging during the 47th (July 2015) scientific cruise of R/V Academic Oparin, near Iturup Island $\left(45^{\circ} 38^{\prime} 9^{\prime \prime} \mathrm{N}, 148^{\circ} 22^{\prime} 6^{\prime \prime} \mathrm{E}\right.$; depth of $54 \mathrm{~m}$ ). EchA was isolated from the sea urchin E. parma according to previous work [19]. The purity of EchA was $>99 \%$ according to the HPLC-MS data (Shimadzu LCMS-2020, Kyoto, Japan).

For EamA and EamB synthesis, $20 \mathrm{mg}$ of echinochrome A was dissolved in $10 \mathrm{~mL}$ of ethanol. Then, $5 \mathrm{~mL}$ of $25 \%$ aqueous ammonia was added, and the mixture was stirred at room temperature. The reaction time was complete in $5 \mathrm{~min}$ and acidified to a $\mathrm{pH}$ of 1 with $12 \%$ hydrochloric acid. The reaction products were extracted with ethyl acetate, the solution was dried with sodium sulphate, and the solvent was removed in vacuo. The residue was chromatographed on a column $(1.1 \times 40 \mathrm{~cm})$ with Sephadex LH-20 (GE Healthcare Bio-Sciences AB, Uppsala, Sweden) using $\mathrm{CHCl}_{3}-\mathrm{MeOH}(8: 1)$ as the eluent. As a result, $8 \mathrm{mg}$ of echinamine $\mathrm{A}$ and $8 \mathrm{mg}$ of echinamine $\mathrm{B}$ were obtained. Each compound was fully characterised by NMR and HPLC-DAD-MS data in comparison with the authentic samples isolated from Scaphechinus mirabilis ([19]; see Supplementary Materials). According to the HPLC-MS data, the purity of echinamines A and B was more than 98\% (Shimadzu LCMS-2020, Kyoto, Japan).

The spinochromes were dissolved in DMSO (Sigma, Saint-Louis, MO, USA) at a concentration $10 \mathrm{mg} / \mathrm{mL}$ and stored at $-20{ }^{\circ} \mathrm{C}$. For cytotoxicity and anti-HSV-1 activity determination, the stock solutions were diluted with DMEM so that the final concentration of DMSO was $0.5 \%$. 
For spectrophotometric studies, $3 \mathrm{~mL}$ of either $\mathrm{EtOH} / \mathrm{HCl}(\mathrm{pH} 2.0)$, $\mathrm{PBS}$ buffer ( $\mathrm{pH} 7.2$ ), or $\operatorname{DMEM}$ (pH 7.2) was first placed in the UV cuvette $(10 \mathrm{~mm})$, and then a $20 \mu \mathrm{L}$ aliquot of the $5 \mathrm{mg} / \mathrm{mL}$ methanolic solution of the spinochromes was added. The absorbance was recorded in comparison to the corresponding solvent using a UV 1800 spectrophotometer (Shimadzu USA Manufacturing Inc. Canby, OR, USA).

\subsection{Cytotoxicity of the Tested Compounds}

The cytotoxicity evaluation of the studied compounds was performed using the MTT assay, as previously described [45]. In brief, confluent Vero cells in 96-well microplates were incubated with two-fold serial dilutions of the tested compounds $(1-1000 \mu \mathrm{g} / \mathrm{mL})$ at $37^{\circ} \mathrm{C}$ for $72 \mathrm{~h}\left(5 \% \mathrm{CO}_{2}\right)$. Untreated cells were used as controls. Then MTT solution $(5 \mathrm{mg} / \mathrm{mL})$ was added, and the cells were incubated at $37^{\circ} \mathrm{C}$ for $2 \mathrm{~h}$. After dissolution of formazan crystals, optical densities were read at $540 \mathrm{~nm}$ (Labsystems Multiskan RC, Vantaa, Finland). The 50\% cytotoxic concentrations $\left(\mathrm{CC}_{50}\right)$ of the tested compounds able to reduce cell viability by $50 \%$ were calculated using regression analysis-generated data from three independent experiments [46].

\subsection{Anti-HSV-1 Activity of the Tested Compounds}

The inhibitory effects of the tested compounds on HSV-1 replication cycle stages in Vero cells were evaluated by the plaque reduction assay [47,48]. Vero cell monolayers grown in 24 -well plates $\left(1 \times 10^{5}\right.$ cells/well) were infected with $100 \mathrm{PFU} / \mathrm{mL}$ of HSV-1. The tested compounds and Acyclovir ${ }^{\circledR}$ were used at concentrations from 0.1 to $100 \mu \mathrm{g} / \mathrm{mL}$.

- Virucidal assay (the pretreatment of the HSV-1 with compounds). HSV-1 suspension was pre-incubated with an equal volume of DMEM or various concentrations of tested compounds for $1 \mathrm{~h}$ at $37^{\circ} \mathrm{C}$, then the mixture was used to infect cellular monolayers. After viral adsorption for $1 \mathrm{~h}$ at $37^{\circ} \mathrm{C}$, the plates were washed, covered with the maintenance medium (DMEM) containing $1 \% \mathrm{CMC}$ for $72 \mathrm{~h}$ at $37^{\circ} \mathrm{C}\left(5 \% \mathrm{CO}_{2}\right)$ until plaques formed.

- Time-of-addition assay. The tested compounds, at various concentrations, were added to cells at $1 \mathrm{~h}$ before viral infection (pretreatment of cells), at the same time with infection (simultaneous treatment) or $1 \mathrm{~h}$ after infection (post-treatment). To study a preventive effect, the cells were pretreated with compounds for $1 \mathrm{~h}$, then infected with HSV-1 for $1 \mathrm{~h}$ after removal of compounds by washing and overlaid with DMEM with $1 \%$ CMC. To study the effect on virus adsorption, cells were treated with compounds and simultaneously infected with HSV-1, then overlaid with DMEM with $1 \%$ CMC after removal of the compounds and unbound virus by washing at $1 \mathrm{~h}$ after adsorption. To study the effect on the early stage of virus replication, the cells were infected with the HSV- 1 for $1 \mathrm{~h}$, and then overlaid with DMEM with $1 \%$ CMC containing different concentrations of the studied compounds after removal of virus by washing. Within all procedures, the cells were incubated for $72 \mathrm{~h}$ at $37^{\circ} \mathrm{C}\left(5 \% \mathrm{CO}_{2}\right)$ until plaques formed.

The attachment and penetration assays were performed as described previously [48,49].

- The attachment assay. Pre-chilled at $4^{\circ} \mathrm{C}$ for $1 \mathrm{~h}$ Vero cells were infected with the virus (100 PFU/mL), and incubated for $3 \mathrm{~h}$ at $4{ }^{\circ} \mathrm{C}$ with different concentrations of the studied compounds. Then, the compounds and unbound viruses were washed away with cold PBS. The cells were supplied with DMEM containing $1 \% \mathrm{CMC}$ and incubated for $72 \mathrm{~h}$ at $37{ }^{\circ} \mathrm{C}\left(5 \% \mathrm{CO}_{2}\right)$ until plaques formed.

- The penetration assay. Pre-chilled at $4^{\circ} \mathrm{C}$ for $1 \mathrm{~h}$ Vero cells were infected with the virus $(100 \mathrm{PFU} / \mathrm{mL})$, and incubated for $3 \mathrm{~h}$ at $4{ }^{\circ} \mathrm{C}$. The unbound viruses were removed with cold PBS, the cells were treated with medium containing different concentrations of the compounds, and then incubated for $1 \mathrm{~h}$ at $37^{\circ} \mathrm{C}$. Viruses that did not enter cells were inactivated with citrate buffer ( $\mathrm{pH}$ 3.0). Then, the cells were washed with PBS, supplied with DMEM containing 1\% CMC, and incubated for $72 \mathrm{~h}$ at $37^{\circ} \mathrm{C}\left(5 \% \mathrm{CO}_{2}\right)$ until plaques formed. 
In all assays, after $72 \mathrm{~h}$ of incubation, the cells were fixed with cold ethanol for $20 \mathrm{~min}$, stained with solution of $0.5 \%$ crystal violet in $20 \%$ ethanol, and the viral plaques were then counted. The plaque formation inhibition rate was calculated according to the following formula [36]: plaque inhibition $(\%)=100-\left[\left(\mathrm{P}_{\mathrm{T}} / \mathrm{P}_{\mathrm{C}}\right) \times 100\right]$, where $\mathrm{P}_{\mathrm{T}}$ and $\mathrm{P}_{\mathrm{C}}$ refer to the number of plaques in the compound-treated cells and the virus-infected cells, respectively. The $\mathrm{IC}_{50}$ of each compound was determined as the concentration that inhibited $50 \%$ of viral plaque formation, compared to virus-infected cells, and was calculated using a regression analysis of the dose-response curve [46]. The SI was calculated as the ratio of $\mathrm{CC}_{50}$ to $\mathrm{IC}_{50}$ for each compound.

\subsection{Measurement of the ROS Level}

The ROS level was measured in the control, the HSV-1-treated cells, and in the same cells with the presence of EchA, EamA, and EamB using the ROS indicator DCF-DA according to prior work [8] with some changes. Treated cells were incubated with $10 \mu \mathrm{M}$ of DCF-DA for $30 \mathrm{~min}$ at $37^{\circ} \mathrm{C}$ in the dark. After washing twice with PBS, the intensity of DCF fluorescence of the cells was measured at an $\lambda_{\text {ex }}$ of $485 \mathrm{~nm} / \lambda_{\mathrm{em}} 520 \mathrm{~nm}$ using the PHERAstar FS plate reader (BMG Labtech, Offenburg, Germany).

For all experiments, a monolayer of Vero cells was prepared. Vero cells were seeded in 96-well plates $\left(1 \times 10^{4}\right.$ cells/well $)$ and cultured for $24 \mathrm{~h}$ at $37^{\circ} \mathrm{C}$ in $5 \% \mathrm{CO}_{2}$. The following experiments were performed; each was carried out in three independent replicates.

- ROS production in HSV-1-infected cells: Cells were treated with HSV-1 (100 PFU/mL) and cultured at $37^{\circ} \mathrm{C}$. After 1, 2, 3, and $4 \mathrm{~h}$, the cells were washed with PBS and the ROS level was measured in infected (HSV-1) and uninfected cells (control).

- ROS production in control cells with the presence of spinochromes: The monolayer of cells treated with the tested spinochromes $(5 \mu \mathrm{g} / \mathrm{mL}, 100 \mu \mathrm{L} /$ well $)$ and incubated for $2 \mathrm{~h}$ at $37^{\circ} \mathrm{C}$. After washing with PBS, the ROS level was measured. Untreated cells were used as the control.

- ROS production in control and HSV-1-infected cells with the presence of spinochromes: HSV-1 (100 $\mathrm{PFU} / \mathrm{mL})$ was mixed with the tested spinochromes $(5 \mu \mathrm{g} / \mathrm{mL})$ in a 1:1 $(v / v)$ ratio and incubated for $1 \mathrm{~h}$ at $37^{\circ} \mathrm{C}$. Then, the mixture and HSV-1 (100 PFU/mL) were applied to a monolayer of Vero cells. After $1 \mathrm{~h}$ of incubation at $37^{\circ} \mathrm{C}$, the cells were washed with PBS and the ROS level was measured. Uninfected and HSV-1-infected cells were used as the control.

\subsection{Molecular Docking}

We used the crystal structure of echinochrome A (CCDC ID NERLUS code) [50,51]. The structures of Eam A and Eam B were obtained using the molecular editor of the MOE 2019.01 [52] program. The structures of the spinochromes were optimised with the forcefield MMFF94, and the structures of the protomers in the aqueous phase were calculated using MOE 2019.01 software. The crystal structures of the complexes of the HSV-1 gD glycoprotein with the nectin-1 receptor (PDB ID 3UKS) and the HSEA/M receptor (PDB ID 1JMA) were used as a target protein. The structure of the HS tetrasaccharide was obtained from the PDB database (PDB ID 1T8U) and used to obtain 3-O-S HS using the molecular editor MOE 2019.01. For molecular docking, a 3-O-S HS structure was used, which was solvated in the aqueous phase and optimised with the forcefield Amber10:EHT. The calculation of the electrostatic potential of the molecular surface of glycoprotein $\mathrm{gD}$ was carried out using the MOE 2019.01 program. Molecular docking of glycoprotein gD with the spinochromes and 3-OS HS was performed using the Dock module of the MOE 2019.01 software. The structures of 30 complexes were calculated with Score London dG, and the 10 most energetically advantageous complexes were optimised with Score GBVI/WSA dG. Contact analysis was carried out using the Ligand Interaction module of the MOE program. 


\subsection{Statistical Analysis}

Statistica 10.0 software was used for statistical analysis of the experimental data. The results are given as the mean \pm standard deviation (SD). Wilcoxon test was used for estimating the differences significant at $p \leq 0.05$ between means of the control and experimental groups.

\section{Conclusions}

Thus, we found that spinochromes of the sea urchin Echinarachnius parma collected at a depth of more than $50 \mathrm{~m}$ exhibited significant anti-HSV-1 activity, mainly due to their direct virucidal properties, and their activity increased in the following order: EchA $<$ EamA $<$ EamB. They also inhibited the attachment of the virus to cells and, to a lesser extent, the entry of the virus into cells. One of the mechanisms of anti-HSV-1 activity of spinochromes is due to the fact that the compounds under study can directly bind to $\mathrm{gD}$, competing with cellular receptors for the binding sites of this protein, thereby preventing the adsorption of HSV-1 on cells. Another mechanism of the antiviral action of the spinochromes, which have pronounced antioxidant properties, is due to a decrease in the HSV-1-induced ROS level in the cells.

Echinochrome A sodium salt is a Histochrome drug permitted for clinical application in Russia for the treatment of myocardial infarction and ophthalmological diseases. The ability of EchA to overcome the blood-brain barrier and to inactivate neurotropic viruses such as HSV-1 and tick-borne encephalitis virus makes it a prospective agent for new therapeutic use [15]. Echinamines A and B are the closest structural analogues of EchA. Their low molecular weight, comparable to EchA cytotoxicity, variety of their synthesis pathways with high yield, and more significant antiherpetic activity reported here, open perspectives to investigate their potential for clinical application.

Supplementary Materials: The following are available online at http://www.mdpi.com/1660-3397/18/11/550/s1, Figure S1: HPLC of products of echinochrome A amination reaction. Figure S2: The structures of echinochrome A, echinamine A and echinamine B protomers in the aqueous phase ( $\mathrm{pH} 7$ ) were calculated using the MOE 2019.01 software. Figure S3: Anti-HSV-1 activity of tested compounds in virucidal assay. Figure S4: The gD binding site, defined by the Site Finder module, that overlaps with the $\mathrm{gD}$ binding site for the nectin-1 cellular receptor (PDB ID 3SKU).

Author Contributions: Formal analysis, E.A.V. and D.V.T.; funding acquisition, P.S.D.; investigation, N.P.M., N.V.K., O.V.I., E.A.V. and S.A.F.; methodology, N.V.K., O.V.I., G.N.L. and E.A.P.; software, G.N.L.; supervision, N.P.M. and S.A.F.; visualization, G.N.L. and D.V.T.; writing-original draft, N.P.M., N.V.K., E.A.V. and G.N.L.; writing-review and editing, P.S.D. and S.A.F. All authors have read and agreed to the published version of the manuscript.

Funding: This research was funded by the Ministry of Science and Higher Education of Russian Federation, grant number 13.1902.21.0012 (075-15-2020-796) «Fundamental Problems of Study and Conservation of Deep-Sea Ecosystems in Potentially Ore-Bearing Areas of the Northwestern Pacific».

Conflicts of Interest: The authors declare no conflict of interest.

\section{References}

1. WHO. Herpes Simplex Virus. News Bulletin. 2016. Available online: https://www.who.int/news-room/factsheets/detail/herpes-simplex-virus (accessed on 22 October 2020).

2. Banerjee, A.; Kulkarni, S.; Mukherjee, A. Herpes Simplex Virus: The Hostile Guest That Takes Over Your Home. Front. Microbiol. 2020, 11, 1-18. [CrossRef]

3. Piret, J.; Boivin, G. Resistance of Herpes Simplex Viruses to Nucleoside Analogues: Mechanisms, Prevalence, and Management. Antimicrob. Agents Chemother. 2011, 55, 459-472. [CrossRef]

4. Turner, L.D.; Beckingsale, P. Acyclovir-resistant herpetic keratitis in a solid-organ transplant recipient on systemic immunosuppression. Clin. Ophthalmol. 2013, 7, 229-232. [CrossRef]

5. Pan, D.; Kaye, S.B.; Hopkins, M.; Kirwan, R.; Hart, I.J.; Coen, D.M. Common and new acyclovir resistant herpes simplex virus-1 mutants causing bilateral recurrent herpetic keratitis in an immunocompetent patient. J. Infect. Dis. 2014, 209, 345-349. [CrossRef] 
6. Santana, S.; Sastre, I.; Recuero, M.; Bullido, M.J.; Aldudo, J. Oxidative stress enhances neurodegeneration markers induced by herpes simplex virus type 1 infection in human neuroblastoma cells. PLoS ONE 2013, 8, e75842. [CrossRef]

7. Georgieva, A.; Vilhelmova, N.; Muckova, L.; Tzvetanova, E.; Alexandrova, A.; Milevaet, M. Alterations in Oxidative Stress Parameters in MDBK Cells, Infected by Herpes Simplex Virus-1. Compt. Rend. Acad. Bulg. Sci. 2017, 70, 731-738.

8. Marino-Merlo, F.; Papaianni, E.; Frezza, C.; Pedatella, S.; De Nisco, M.; Macchi, B.; Grelli, S.; Mastino, A. NF- $\kappa$ B-Dependent Production of ROS and Restriction of HSV-1 Infection in U937 Monocytic Cells. Viruses 2019, 11, 428. [CrossRef]

9. Firuzi, O.; Miri, R.; Tavakkoli, M.; Saso, L. Antioxidant therapy: Current status and future prospects. Curr. Med. Chem. 2011, 18, 3871-3888. [CrossRef]

10. Balakrishnan, D.; Kandasamy, D.; Nithyanand, P. A review on antioxidant activity of marine organisms. Int. J. Chem. Tech. Res. 2014, 6, 3431-3436.

11. Torky, Z.A.; Hossain, M.M. Pharmacological evaluation of the hibiscus herbal extract against herpes simplex virus-type 1 as an antiviral drug in vitro. Int. J. Virol. 2017, 13, 68-79. [CrossRef]

12. Thomson, R.H. Naturally Occurring Quinones, 2nd ed.; Academic Press: London, UK; New York, NY, USA, $1971 ; 734 p$.

13. Hou, Y.; Vasileva, E.A.; Carne, A.; McConnell, M.; Bekhit, A.E.D.A.; Mishchenko, N.P. Naphthoquinones of the spinochrome class: Occurrence, isolation, biosynthesis and biomedical applications. RSC Adv. 2018, 8, 32637-32650. [CrossRef]

14. Shikov, A.N.; Pozharitskaya, O.N.; Krishtopina, A.S.; Makarov, V.G. Naphthoquinone pigments from sea urchins: Chemistry and pharmacology. Phytochem. Rev. 2018, 17, 509-534. [CrossRef]

15. Fedoreyev, S.A.; Krylova, N.V.; Mishchenko, N.P.; Vasileva, E.A.; Pislyagin, E.A.; Iunikhina, O.V.; Lavrov, V.F.; Svitich, O.A.; Ebralidze, L.K.; Leonova, G.N. Antiviral and antioxidant properties of echinochrome A. Mar. Drugs 2018, 16, 509. [CrossRef]

16. Krylova, N.V.; Leneva, I.A.; Fedoreev, S.A.; Ebralidze, L.K.; Mishchenko, N.P.; Vasileva, E.A.; Falynskova, I.N.; Iunikhina, O.V.; Lavrov, V.F.; Svitich, O.A. Activity of compounds containing echinochrome A against herpes simplex virus type 2 in vitro and in vivo. J. Microbiol. Epidemiol. Immunobiol. 2019, 6, 56-64. [CrossRef]

17. Rubilar Panasiuk, C.T.; Barbieri, E.S.; Gázquez, A.; Avaro, M.; Vera Piombo, M.; Gittardi Calderón, A.A.; Seiler, E.N.; Fernandez, J.P.; Sepúlveda, L.R.; Chaar, F. In Silico Analysis of Sea Urchin Pigments as Potential Therapeutic Agents Against SARS-CoV-2: Main Protease (Mpro) as a Target. ChemRxiv 2020. [CrossRef]

18. Barbieri, E.S.; Rubilar Panasiuk, C.T.; Gázquez, A.; Avaro, M.; Seiler, E.N.; Vera Piombo, M.; Gittardi Calderón, A.A.; Chaar, F.; Fernandez, J.P.; Sepúlveda, L.R. Sea Urchin Pigments as Potential Therapeutic Agents Against the Spike Protein of SARS-CoV-2 Based on in Silico Analysis. ChemRxiv 2020. [CrossRef]

19. Mischenko, N.P.; Fedoreyev, S.A.; Pokhilo, N.D.; Anufriev, V.P.; Denisenko, V.A.; Glazunov, V.P. Echinamines $\mathrm{A}$ and B, first aminated hydroxynaphthazarins from the sea urchin Scaphechinus mirabilis. J. Nat. Prod. 2005, 68, 1390-1393. [CrossRef] [PubMed]

20. Vasileva, E.A.; Mishchenko, N.P.; Zadorozhny, P.A.; Fedoreyev, S.A. New aminonaphthoquinone from the sea urchins Strongylocentrotus pallidus and Mesocentrotus nudus. Nat. Prod. Commun. 2016, 11, 821-824. [CrossRef]

21. Zhou, D.Y.; Qin, L.; Zhu, B.W.; Wang, X.D.; Tan, H.; Yang, J.F.; Li, D.M.; Dong, X.P.; Wu, H.T.; Sun, L.M. Extraction and antioxidant property of polyhydroxylated naphthoquinone pigments from spines of purple sea urchin. Food Chem. 2011, 129, 1591-1597. [CrossRef]

22. Vasileva, E.A.; Mishchenko, N.P.; Fedoreyev, S.A. Diversity of polyhydroxynaphthoquinone pigments in North Pacific sea urchins. Chem. Biodivers. 2017, 14, e1700182. [CrossRef]

23. Hou, Y.; Vasileva, E.A.; Mishchenko, N.P.; Carne, A.; McConnell, M.; Bekhit, A.E.A. Extraction, structural characterization and stability of polyhydroxylated naphthoquinones from shell and spine of New Zealand sea urchin (Evechinus chloroticus). Food Chem. 2019, 272, 379-387. [CrossRef]

24. Powell, C.; Hughes, A.D.; Kelly, M.S.; Conner, S.; McDougall, G.J. Extraction and identification of antioxidant polyhydroxynaphthoquinone pigments from the sea urchin, Psammechinus miliaris. LWT-Food Sci. Technol. 2014, 59, 455-460. [CrossRef]

25. Soleimani, S.; Yousefzadi, M.; Moe, S. Antibacterial and antioxidant characteristics of pigments and coelomic fluid of sea urchin, Echinodermata Mathaei species, from the Persian Gulf. J. Kerman Univ. Med. Sci. 2015, $22,614-628$. 
26. Kuwahara, R.; Hatate, H.; Yuki, T.; Murata, H.; Tanaka, R.; Hama, Y. Antioxidant property of polyhydroxylated naphthoquinone pigments from shells of purple sea urchin Anthocidaris crassispina. LWT-Food Sci. Technol. 2009, 42, 1296-1300. [CrossRef]

27. Brasseur, L.; Hennebert, E.; Fievez, L.; Caulier, G.; Bureau, F.; Tafforeau, L.; Flammang, P.; Gerbaux, P.; Eeckhaut, I. The roles of spinochromes in four shallow water tropical sea urchins and their potential as bioactive pharmacological agents. Mar. Drugs 2017, 15, 179. [CrossRef]

28. Pokhilo, N.D.; Shuvalova, M.I.; Lebedko, M.V.; Sopelnyak, G.I.; Yakubovskaya, A.Y.; Mischenko, N.P.; Fedoreyev, S.A.; Anufriev, V.P. Synthesis of Echinamines A and B, the first aminated hydroxynaphthazarins produced by the sea urchin Scaphechinus mirabilis and Its Analogues. J. Nat. Prod. 2006, 69, 1125-1129. [CrossRef] [PubMed]

29. Mel'man, G.I.; Mishchenko, N.P.; Denisenko, V.A.; Berdyshev, D.V.; Glazunov, V.P.; Anufriev, V.F. Amination of 2-hydroxy-and 2, 3-dihydroxynaphthazarins. Synthesis of echinamines A and B, metabolites produced by the sand dollar Scaphechinus mirabilis. Russ. J. Org. Chem. 2009, 45, 37-43. [CrossRef]

30. Pokhilo, N.D.; Yakubovskaya, A.Y.; Denisenko, V.A.; Anufriev, V.P. Regiospecificity in the reaction of 2,3-dichloronaphthazarins with azide anions. Synthesis of echinamine A-A metabolite produced by the sea urchin Scaphechinus mirabilis. Tetrahedron Lett. 2006, 47, 1385-1387. [CrossRef]

31. Polonik, S.G.; Polonik, N.S.; Denisenko, V.A.; Moiseenko, O.P.; Anufriev, V.F. Synthesis and transformation of 2-amino-3-hydroxynaphthazarin. Russ. J. Org. Chem. 2009, 45, 1410-1411. [CrossRef]

32. Polonik, N.S.; Anufriev, V.P.; Polonik, S.G. Short and Regiospecific Synthesis of Echinamine A-The Pigment of Sea Urchin Scaphechinus mirabilis. Nat. Prod. Commun. 2011, 6, 217-222.

33. Greenwood, J.R.; Calkins, D.; Sullivan, A.P.; Shelley, J.C. Towards the comprehensive, rapid, and accurate prediction of the favorable tautomeric states of drug-like molecules in aqueous solution. J. Comput. Aided Mol. Des. 2010, 24, 591-604. [CrossRef]

34. Shelley, J.C.; Cholleti, A.; Frye, L.L.; Greenwood, J.R.; Timlin, M.R.; Uchimaya, M. Epik: A software program for $\mathrm{pK}_{\mathrm{a}}$ prediction and protonation state generation for drug-like molecules. J. Comput. Aided Mol. Des. 2007, 21, 681-691. [CrossRef]

35. Petukh, M.; Stefl, S.; Alexov, E. The role of protonation states in ligand-receptor recognition and binding. Curr. Pharm. Des. 2013, 19, 4182-4190. [CrossRef]

36. Dai, W.; Wu, Y.; Bi, J.; Wang, S.; Li, F.; Kong, W.; Barbier, J.; Cintrat, J.C.; Gao, F.; Gillet, D.; et al. Antiviral Effects of ABMA against Herpes Simplex Virus Type 2 In Vitro and In Vivo. Viruses 2018, 10, 119. [CrossRef]

37. Klysik, K.; Pietraszek, A.; Karewicz, A.; Nowakowska, M. Acyclovir in the Treatment of Herpes Viruses -A Review. Curr. Med. Chem. 2020, 27, 4118-4137. [CrossRef]

38. Tai, C.J.; Li, C.L.; Tai, C.J.; Wang, C.K.; Lin, L.T. Early Viral Entry Assays for the Identification and Evaluation of Antiviral Compounds. J. Vis. Exp. 2015, 104, e53124. [CrossRef]

39. Wang, G.; Hernandez, R.; Weninger, K.; Brown, D.T. Infection of cells by Sindbis virus at low temperature. Virology 2007, 362, 461-467. [CrossRef]

40. Akhtar, J.; Shukla, D. Viral entry mechanisms: Cellular and viral mediators of herpes simplex virus entry. FEBS J. 2009, 276, 7228-7236. [CrossRef]

41. Luo, Z.; Kuang, X.P.; Zhou, Q.Q.; Yan, C.Y.; Li, W.; Gong, H.B.; Kurihara, H.; Li, W.X.; Li, Y.F.; He, R.R. Inhibitory effects of baicalein against herpes simplex virus type 1. Acta Pharm. Sin. B 2020, in press. [CrossRef]

42. Arii, J.; Kawaguchi, Y. The Role of HSV Glycoproteins in Mediating Cell Entry. In Human Herpesviruses. Advances in Experimental Medicine and Biology; Kawaguchi, Y., Mori, Y., Kimura, H., Eds.; Springer: Singapore, 2018; Volume 1045, pp. 3-21.

43. O'Donnell, C.D.; Kovacs, M.; Akhtar, J.; Valyi-Nagy, T.; Shukla, D. Expanding the role of 3-O sulfated heparan sulfate in herpes simplex virus type-1 entry. Virology 2010, 397, 389-398. [CrossRef]

44. Li, W.; Xu, C.; Hao, C.; Zhang, Y.; Wang, Z.; Wang, S.; Wang, W. Inhibition of herpes simplex virus by myricetin through targeting viral gD protein and cellular EGFR/PI3K/Akt pathway. Antivir. Res. 2020, 177, 104714. [CrossRef]

45. Mosmann, T. Rapid colorimetric assay for cellular growth and survival: Application to proliferation and cytotoxicity assays. J. Immunol. Methods 1983, 65, 55-63. [CrossRef] 
46. Weislow, O.S.; Kiser, R.; Fine, D.L.; Bader, J.; Shoemaker, R.H.; Boyd, M.R. New soluble-formazan assay for HIV-1 cytopathic effects: Application to high-flux screening of synthetic and natural products for AIDS-antiviral activity. J. Natl. Cancer Inst. 1989, 81, 577-586. [CrossRef]

47. Killington, R.A.; Powell, K.L. Growth, assay, and purification of herpesviruses. In Virology: A Practical Approach; Mahy, B.W., Ed.; IRL Press: Oxford, UK, 1991; pp. 207-236.

48. Marcocci, M.E.; Amatore, D.; Villa, S.; Casciaro, B.; Aimola, P.; Franci, G.; Grieco, P.; Galdiero, M.; Palamara, A.T.; Mangoni, M.L.; et al. The Amphibian Antimicrobial Peptide Temporin B Inhibits In Vitro Herpes Simplex Virus 1 Infection. Antimicrob. Agents Chemother. 2018, 62, e02367. [CrossRef]

49. Cardozo, F.T.; Camelini, C.M.; Mascarello, A.; Rossi, M.J.; Nunes, R.J.; Barardi, C.R.; de Mendonca, M.M.; Simoes, C.M. Antiherpetic activity of a sulfated polysaccharide from Agaricus brasiliensis mycelia. Antivir. Res. 2011, 92, 108-114. [CrossRef]

50. Groom, C.R.; Bruno, I.J.; Lightfoot, M.P.; Ward, S.C. The Cambridge Structural Database. Acta Cryst. 2016, B72, 171-179. [CrossRef]

51. Gerasimenko, A.V.; Fedoreev, S.A.; Mishchenko, N.P. Molecular and Crystal Structure of the Echinochrome Complex with Dioxane. Krist. Russ. Crystallogr. Rep. 2006, 51, 42-47. [CrossRef]

52. Molecular Operating Environment (MOE); Chemical Computing Group ULC: Montreal, QC, Canada, 2019.

Publisher's Note: MDPI stays neutral with regard to jurisdictional claims in published maps and institutional affiliations.

(C) 2020 by the authors. Licensee MDPI, Basel, Switzerland. This article is an open access article distributed under the terms and conditions of the Creative Commons Attribution (CC BY) license (http://creativecommons.org/licenses/by/4.0/). 